DOI: 10.46340/eppd.2021.8.3.15

\author{
Oleksandr Novytskyi \\ ORCID ID: https://orcid.org/0000-0002-1055-1629 \\ South Ukrainian National Pedagogical University named after K.D. Ushynsky, \\ Odessa, Ukraine
}

\title{
THE COVID-19 PANDEMIC AS A TRIGGER FOR SOCIO-POLITICAL CHANGE
}

\author{
Олександр Новицький \\ Південноукраїнський національний педагогічний університет імені К.Д. Ушинського, \\ Одеса, Україна
}

\section{ПАНДЕМІЯ COVID-19 ЯК ТРИГЕР СОЦАЛЬНО-ПОЛІТИЧНИХ ЗМІН}

\begin{abstract}
A pandemic in today's world can be a big problem. Importantly, viruses have a much greater chance of spreading than before. People can easily move from one continent to another. In addition, the world's population has grown significantly and the number of social connections and communications has increased. People live in big cities, which are harder to isolate.

Research in this area has only just begun to develop. Now we can observe various discussions about the virus, its impact on the development of society, the state, different types of relationships. To more fully characterize this situation, knowledge in various fields of science should be used, in particular, medicine, biology, geography, sociology, psychology, law, political science, international relations, etc.

Now it is extremely important to study the manifestations of explosive public activity from the point of view of causation, because the general attention to the problem is one thing, but panic, chaos and hysteria are another things. That is, COVID-19 clearly worked as a political trigger, which in essence affects the vast majority, excites the primary instincts and works on the mechanisms of disgust, fear and time constraints. Speaking of public activity, it is noticeable that the population pays close attention to the state of the health care system in their countries and to the effectiveness of the state's policy in this direction. As a result, politicians and their actions are severely criticized. The attention of the population is focused on official channels, statistics of diseases and mortality, active discussion of what is happening on social networks.

The COVID-19 pandemic has been a trigger that has shown the devastating large-scale imbalances that have accumulated in world politics and economics over the past decades. In turn, methods of combating the spread of the pandemic in the form of widespread quarantine and forced isolation of large masses of the population, limiting its mobility and economic activity, have created an unprecedented socio-economic and political situation. Many countries were forced to sacrifice their economies in favor of the imperative of saving the population.
\end{abstract}

Keywords: socio-political changes, political process, pandemic, coronavirus, trigger, political power.

Постановка проблеми. 2019 рік став для світу початком нового етапу в розвитку людських відносин, відносин між державами. Тригером цих змін став на той час невідомий вірус, який прийшов 3 Китаю. Згодом його було визначено як Коронавірусну інфекцію COVID-19. На сьогодні вірус набув статусу пандемії та $\epsilon$ глобальною проблемою усього людства. Як визначає Т. Ткаченко, «2020 рік $€$ початком нового циклу, рік переходу, що запускає нові геополітичні тенденції, тренди, що впливають на життя соціуму, саме під час таких кризових ситуацій є можливість відформатувати вже застарілі моделі, сформовані структури» ${ }^{1}$.

\footnotetext{
${ }^{1}$ Ткаченко, Т. (2020). Пандемія covid-19 - глобально-емоційний тригер сфери гостинності: особливості і визнання. Актуальные научные исследования в современном мире, 6-4 (62), 56-61.
} 
Аналіз останніх досліджень і публікацій. Дослідження цього напрямку тільки почали розвиватися. Зараз можемо спостерігати за різноманітними дискусіями щодо вірусу, щодо його впливу на розвиток суспільства, держави, різні типи відносин. Для більш повної характеристики даної ситуації слід використовувати знання в різних галузях науки, зокрема, це медицина, біологія, географія, соціологія, психологія, право, політологія, міжнародні відносини тощо. Безумовно, лідирують медична сфера та психологія. Тут слід відзначити публікації Т.Ткаченко, М. Супотницього, С.Шах. В аспекті філософії, права, міжнародних відносин та політології цікавими є публікації І.Яцик, В.Луканової, Н.Гуменюк, П.Клімкина, Г.Шелест, С.Сидоренко, С.Герасимчук, М. Міщенко, Н.Хамітова. Але оскільки напрям тільки почав розвиватися, то й недосліджених питань дуже багато. Зокрема, пандемія COVID-19 як тригер соціально-політичних змін. світу.

Mema cmammi: визначити роль пандемії COVID-19 в соціально-політичних змінах сучасного

Виклад основного матеріалу. Слід почати з розуміння того, що ж таке пандемія. Словник української мови 1975 року дає наступне визначення: «Пандемія - це найвищий ступінь розвитку епідемії, що поширилась на більшість населення однієї чи кількох країн. Якщо хвороба охоплює одночасно багато людей, виникає епідемія, яка може перерости в пандемію, наприклад, пандемію грипу, яка іноді уражає населення кількох країн» ${ }^{1}$.

Пандемія - це поширення захворювання в світових масштабах. Вона відбувається тоді, коли 3'являється новий вірус, який поширюється по всьому світу, а населення не має імунітету до вірусу, а також ефективних засобів профілактики, тобто вакцинації чи лікування.

Пандемія в сучасному світі може стати великою проблемою. Важливим $\epsilon$ те, що у вірусів 3'явилося значно більше можливостей для поширення, ніж раніше. Люди легко можуть переміщуватися $з$ одного контенту на інший. До того ж кількість населення світу значно зросла та збільшилася кількість соціальних зв'язків і комунікацій. Люди живуть у великих містах, які важче ізолювати.

Крім того, «виникнення паніки, коли люди намагаються покинути епіцентр спалаху, може привести до ще більшого розповсюдження хвороби. Виготовлення вакцини може зайняти місяці або роки, тому що пандемічні віруси є новими агентами. Медичні установи будуть перевантажені, і може виникнути нестача персоналу для надання екстреної допомоги хворим вірусом та іншим людям, які хворіють звичайними захворюваннями» ${ }^{2}$.

«Пандемія COVID-19 є найбільшим викликом, 3 яким світова спільнота стикалася з 1940-х років. У ті роки, після двох руйнівних світових війн, політичні лідери об'єдналися задля створення нової багатосторонньої системи (йдеться про ООН та низку міжнародних конвенцій, які охопили весь cвim. ). Цілі були зрозумілими: об’єднати країни, розвіяти спокуси ізоляціонізму і націоналізму та вирішити проблеми, які можуть бути врегульовані лише спільними зусиллями в дусі солідарності і співробітництва, а саме миру, процвітання, здоров'я і безпеки. Сьогодні ми сподіваємося, що зі спільною боротьбою з пандемією COVID-19 ми зможемо побудувати міцнішу міжнародну архітектуру охорони здоров'я, яка захистить майбутні покоління» ${ }^{3}$.

Звісно, пандемія коронавірусу не $\epsilon$ першою в світі. I раніше історії відомі різні пандемії. Це $\epsilon$ холера, чума, «іспанка», Ебола, СНІД, лихоманка Західного Нілу тощо. «Але все це - окремі види пандемії, кожна 3 них має власну клінічну картину, кожна 3 них виникає в окремих соціокультурних, історично-політичних, економіко-географічних обставинах» ${ }^{4}$.

Із самого початку ситуація 3 коронавірусом сприймалася людьми з різним ступенем байдужості: хтось дивився рідкісні новини про ситуацію в Китаї з часткою співчуття до людей; хтось - із цинізмом; хтось зовсім не розумів, чому це повинно стосуватися сааме його, коли вірус «так далеко». Реакція була різною, але переважна більшість навряд чи могла уявити, що в найкоротші

\footnotetext{
${ }_{1}^{1}$ Білодід, І. К. (ред.) (1975). Словник украӥнської мови: в 11 томах. Київ: Наукова думка, 6, 43.

2 Лукашевская,А. (2020).Что такое пандемия и эпидемия: объясняем разницу на примере коронавируса. 3доровье.24. <https://health.24tv.ua/ru/chto_takoe_pandemija_chto_takoe_jepidemija_raznica_jetih_ponjatij_n1287883> (2021,травень, 15).

${ }^{3}$ Свропейська правда. Міжнародна безпека та євроінтеграція україни (2021). Колективне комюніке керівників вооз, європейської ради, а також лідерів украӥни та 22 країн світу. Як здолати пандемію: спільна стаття 24 глав держав та урядів. <https://www.eurointegration.com.ua/articles/2021/03/30/7121495> (2021, травень, 15). 4 Луканова, В. (2018) Пандемія як антисистема: аналіз конститутивних аспектів. Науково-теоретичний альманах Грані, 21, 11, 89.
} 
терміни COVID-19 буде оголошений світовою пандемією. У певному сенсі те, як Китай першим намагався приборкати поширення вірусу, повинно було дати решті світу якусь відстрочку, щоб підготуватися. Але світ не досить вдало скористався нею.

I тут виникає питання щодо того, що є екстремальна ситуація, про яку все більше говорять, коли мова заходить про коронавірус. Цікавою є позиція І.Яцик, яка у своїй роботі «Гранична ситуація екзистенції вчинку: повнота екзистенції у філософії Ніколо Аббаньяно та «людина на межі» Карла Ясперса» представляє такі характеристики екстремальної ситуації: «необхідність вибору; життєва проблема; потрясіння; те, через що людина мусить або боротись, або померти, або жити з іншими; певній настрій (віра та відчай)». ${ }^{1}$ На нашу думку, це саме такі ознаки, які характеризують коронавірус як екстремальну ситуацію: це проявляється у загальному стані стресу, надзвичайності, небезпечності, неочікуваності, дезадаптації, непрогнозованості тощо. I тут слід погодитися з В.Лукановою, що «коронавірус може спровокувати значну антропологічну екологічну кризу». ${ }^{2}$ На думку вченої, «саме словосполучення «вибух пандемії» вказує на неочікуваний характер. Клінічна картина пандемій, де дуже висока вірогідність летального вироку, робить хворобу дуже небезпечною. Масштаби, які охоплює собою пандемія, безумовно, є надзвичайними. Під час таких подій населення завжди відчуває стресовий стан, внаслідок чого відбувається дезадаптація людей, яка сіє паніку. Це достатньо очевидні речі». ${ }^{3}$

Коронавірус почав свій шлях із Китаю, і коли дістався до країн Європи, наслідки цієї помилки виявилися страшними: в найкоротші терміни країни опинилися у важкій ситуації, яка характеризувалася великою кількістю загиблих, наприклад, в Італії. Лунають думки, що така ситуація стала наслідком моделі ліберального суспільства масового споживання, яка склалася в європейських країнах та виявилася абсолютно не готовою до такої ситуації. Свою ефективність політична система доводить ступенем дієвості реакції на ті чи інші зовнішні виклики та ризики, 3 якими вони несподівано стикаються.

Але слід також зрозуміти, чому саме китайська модель виявилася ефективнішою в боротьбі 3 коронавірусом. Так, Китай використав в повному обсязі жорсткість та мобілізацію в сукупності з адміністративним ресурсом. Дисципліна китайців, яка безпосередньо пов'язана з їхнім менталітетом, опиралася також на вказівки партії. І головне - суспільство добровільно підкорюється цим вказівкам, а партія, в свою чергу, впевнена в такій поведінці суспільства. Така позиція як: «китайці- люди «ми», а не «я», як це відбувається в ліберальних суспільствах, де у фокусі індивідуальність людини, іiі права та свободи.

Також, слід мати на увазі, що уряд Китаю жорстко реагував на будь-які фейки та доручав поліції перевіряти відеоматеріали відеоблогеров, які виїжджають за кордон, щоб вони не поширювали паніку. Уряд оперативно перекрив шляхи, закривав міста, перешкоджаючи переміщенню людей.

Таким чином, азіатські країни показали високу ефективність у протистоянні з цією хворобою.

Що стосується Європи, то суспільство даної моделі зіштовхнулося зі зворотною стороною демократичних свобод - толерантністю, цінністю вільного життя та загальної незалежності. У цих країнах політичні та культурні діячі культивують ідею індивідуальності та свободи. Показовою $є$ ситуація, коли уряд намагався вводити заборону на переміщення, але суспільство невдоволено на це реагувало, аргументуючи тим, що ніхто не має права обмежувати їх переміщення. При цьому паніка посилювалася, з'являлися нові теорії, фейки і тому подібне. В Європі суспільство виявилося не готовими до такої кризи: уряди виявилися не здатними використовувати механіку жорсткого державного управління, а громадяни не звикли виконувати такі рішення. Звідси - невиконання умов карантину, i, як результат, збільшення кількості хворих та померлих. І тут слід погодитися з А.Пехник, що коли ми говоримо про роль влади в життєдіяльності суспільства, то акцент слід робити на питаннях «раціональності та ефективності» ${ }^{4}$.

Зараз надзвичайно важливо досліджувати з точки зору причинно-наслідкових зв'язків прояви вибухової громадської активності, адже загальна увага до проблеми - це одне, але паніка, хаос та

\footnotetext{
${ }^{1}$ Яцик, І. С. (2009). Гранична ситуація екзистенції вчинку: повнота екзистенції у філософії Ніколо Аббаньяно та «людина на межі» Карла Ясперса: дисертачія на здобуття наукового ступеня кандидата філософських наук. Житомир: Житомирський державний університет імені Івана Франка , 56.

2 Луканова, В. (2018). Пандемія як антисистема: аналіз конститутивних аспектів. Науково-теоретичний альманах Грані, 21, 11, 87.

${ }^{3}$ Там само, 90.

${ }^{4}$ Пехник, А. (2017). Розподіл влади: сучасний погляд. Актуальні проблеми політики, 60, 48.
} 
істерія - зовсім інше. Тобто, COVID-19 виразно спрацював як політичний тригер, який за своєю суттю впливає на переважну більшість, збуджує первинні інстинкти та працює на механізмах відрази, страху та обмеженості часу. Говорячи про громадську активність, помітно, що пильна увага населення направлена на стан системи охорони здоров'я у своїх країнах та на ефективність проведеної державою політики в цьому напрямку. Як підсумок, політики та їхні дії піддаються жорсткій критиці. Увага населення прикута до офіційних каналів, статистики захворювань та смертності, активного обговорення того, що відбувається в соціальних мережах.

Фактичні наслідки впливу політичних тригерів, на відміну від тих, механізми яких відомі 3 досліджень в медицині (травма-тригери) та маркетингу (тригери продажів), як правило, вкрай непередбачувані. Саме тому їхній ефект завжди необхідно вивчати, апелюючи до безлічі факторів, від менталітету населення до особливостей економічної системи держави, щоб прораховувати наслідки і нівелювати гірші з них. Такий масштаб громадської реакції пояснюється ще й тим, що люди активно обговорюють не стільки сам вірус, скільки причини його виникнення: одні вірять в біологічну зброю «з пробірки», інші - в природний плин подій і невідворотну еволюцію вірусів, треті ж абсолютно впевнені, що вірусу не існує зовсім і все, що відбувається - теорія змови фармацевтичних компаній.

Дійсно, пандемія COVID-19 стала тригером, який показав руйнівні масштабні дисбаланси, накопичені у світовій політиці та економіці за останні десятиліття. У свою чергу методи боротьби з розповсюдженням пандемії у вигляді повсюдних карантинів і примусових ізоляцій великих мас населення, що обмежують його мобільність та економічну активність, створили безпрецедентну соціально-економічну та політичну ситуацію. Багато країн були вимушені пожертвували економікою на користь імперативу збереження населення. Міжнародний валютний фонд вважає, що результатом боротьби з пандемією стане найглибша з часів Великої депресії глобальна економічна рецесія.

Політичний простір зараз характеризується підвищеним рівнем чутливості міжнародної системи, міжнародних організацій тощо. На думку С.Герасимчук та Г.Шелест «...головним тригером для переваги у використанні тактичних рішень $\epsilon$ широке усвідомлення того, що світовий порядок змінюється, зокрема і через переосмислення своєї ролі в ООН та ВООЗ з боку США». Дійсно, «...пандемічні виклики проявлять, наскільки уряди можуть налагоджувати взаємодію для подолання ризиків, пов'язаних із довгими ланцюгами поставок. В цьому контексті СС може подати приклад ефективної координації процесу відправлення вакцин до держав-членів $€ С$ » ${ }^{\text {. }}$

Ще аспект, на якому слід акцентувати увагу, - це вплив вірусу на чуттєво-емоційний елемент суспільства, наслідком чого $є$ підвищення рівня націоналізму та антиглобальних рухів, спад яких ми спостерігали нещодавно. Пандемія стала тригером постійної зміни представників урядів країн 3 найвищим рівнем захворювання та смертності громадян. На перший план у риториці політичних лідерів виходить популізм та демагогія. Але, з іншого боку, ми будемо спостерігати єднання політичних лідерів, особливо європейських країн. I саме від політичної ситуації, від того, де та коли буде проведено все ж таки чергові вибори, буде залежатиме економічний розвиток.

Загалом зараз дуже складно передбачити, яким чином надалі буде рухатися вірус, якими будуть його мутації, якими будуть наслідки від вакцинації, що може викликати затяжну соціальну та політичну напругу в різних країнах та союзах. «Діагностування пандемії як загрози безпеці може призвести до неліберального оформлення заходів цифрового спостереження удеяких країнах світу». С.Герасимчук та Г.Шелест говорять про так звану «інфодемію», якої, на їхню думку, «не уникнути, а окремі політичні актори навмисно та цілеспрямовано прагнутимуть формувати відчуття безпрецедентно загрозливого стану, для подолання якого необхідний особливий політичний акт (введення надзвичайного стану, карантинні обмеження із відслідкуванням пересування людини, тощо)»².

Такі процеси вплинуть на світовий політичний процес $\mathrm{i}$ можливим $\epsilon$ прогноз щодо неповернення до сталих міжнародних інституцій та альянсів, до демократичних політичних станів. Наприклад, така ситуація може створити сприятливий фон для Росії, яка здавна намагається реалізувати свої імперіалістичні бажання по відношенню до тих регіонів та націй, де існують різні конфліктні та кризисні ситуації. І ми бачимо, що ймовірність виникнення таких регіонів буде тільки збільшуватися по всьому світі. Нерозвинуті країні будуть накопичувати борги та зобов'язання, а це, відповідно, посилює соціальну та політичну напругу та зростає рівень протистоянь між країнами.

\footnotetext{
${ }^{1}$ Герасимчук, С., Шелест, Г. (2020). Сиенарії і тренди 2021: Міжнародна політика. Київ: Фонд імені Фрідріха Еберта, 46.

${ }^{2}$ Там само. 
Звичайно, все це стосується й України і буде відображено на відносинах України із сусідніми державами. Мова йде як про вплив на зовнішню політику, так і внутрішні аспекти життя, економіку, соціалізацію, відносини з СС, відносини з Росією, Молдовою, Кримом, Донбасом тощо. Відповідно, чим складнішою буде пандемічна ситуація, тим складнішими будуть відносини із сусідами, а це буде відзначатися на складі уряду, роботі парламенту, виборах. Держави, які й до цієї кризи не характеризувалися сталими демократичними процесами, з ускладненням ситуації лише зануряться в антидемократичність ще глибше, ще більш швидкими темпами до політичної кризи, до безпреривних переговорів між політичними силами. Безумовно, рівень демократії буде визначати статус країни на міжнародній арені, ії роль у міжнародних відносинах тощо.

Зараз ми це спостерігаємо в Угорщині, де превалює авторитарний фон політичних процесів, i це має тенденцію щодо посилення авторитаризму, зниження рівня дієвості опозиції, до контролю ЗМІ. Можлива нова хвиля популістських політичних сил, які за допомогою маніпуляцій та безпідставних пропозицій перетягнуть на себе відповідні частки суспільства, що буде використано на наступних виборах.

Пандемія на рівні політичних процесів вплинула на всі країни у світі. Деякі практично змінили політичний режим 3 демократичного на авторитарний; деякі- сформували нові уряди на засадах солідарності та взаємодопомоги консолідувалися; деякі- закріпили свої позиції; а деякі - зовсім змінили свій політичний простір. Органи державної та політичної влади змінили засоби діяльності, в політичне життя стійко увійшли інноваційні технології, - тобто зміни невідворотні та інколи, непередбачувані. «Короновірусні вітри вже принесли нові практики дистанційної роботи в органи влади, виборчі та інші новації в політичне життя країн світу. Вочевидь, політична площина «післякарантинного світу» може зазнати не менш докорінних, незворотних і непередбачуваних змін, ніж повсякденне життя людей» ${ }^{1}$.

Щодо України, то за опитуванням, яке проводилося 27-28 березня 2021 року групою «Рейтинг»: «Епідемію коронавірусу особистою проблемою вважають $25 \%{ }^{2}$. Слід відзначити, що в нас ситуація практично завжди однакова - тріумфальні вибори змінюються з часом (1-2 роки) активним розчаруванням. Зараз $є$ така сама ситуація. Були великі очікування від діючого президента України В.Зеленського, які змінилися на зменшення довіри з 77 відсотків до близько 45 відсотків опитаних (за даними станом на 1 квітня $2021^{3}$. «Близько $30 \%$ вважають, що Президент В.Зеленський і Міністерство охорони здоров'я ефективно реагують на загрозу коронавірусу, більше половини опитаних вважають, що неефективно. $18 \%$ вважають ефективним реагування Кабінету Міністрів України і Верховної ради, більше $60 \%$ - неефективним. У порівнянні із листопадом 2020 року спостерігається деяке зниження позитивних оцінок реагування на загрозу коронавірусу органів центральної влади» ${ }^{4}$.

На жаль, це найгірший показник в Європі. Все це ускладнюється ще й тим, що зростає недовіра не тільки до Президента України, а й до органів державної влади, до політичних інститутів тощо. Зокрема, М.Степанову «довіряють 19\%, не довіряють - 37\%, не знають такого - 34\%. Екс-міністру Уляні Супрун довіряють $14 \%$, не довіряють $-61 \%$, не знають $\dddot{11}-17 \%$ » ${ }^{5}$

За даним опитуванням, «головною причиною зростання захворюваності на коронавірус у березні цього року вважають недотримання карантину громадянами (46\%). Далі - сезонне зростання простудних захворювань (32\%), неефективні дії влади (28\%) та виникнення нових форм коронавірусу $(17 \%) »^{6}$.

\footnotetext{
${ }^{1}$ Лабораторія законодавчих ініціатив (2020). Вірус і політика: Як пандемія коронавірусу впливає на політичні прочеси? <https://parlament.org.ua/2020/03/30/virus-i-politika-yak-pandemiya-koronavirusu-vplivaye-na-politichniprotsesi/> (2021, травень, 15).

${ }^{2}$ Соціологічна група Рейтинг (2021). Оиінка медичної сфери в Украӥні (дані на 15.04.2021 p.)

<http://ratinggroup.ua/research/ukraine/ocenka_medicinskoy_sfery_v_ukraine_24-28_marta_2021.html?fbclid= IwAR1r5VhpvQgW9ERicJF5AVuT1EuHbrcgypZxWrZ9ZYRwBF7izYM0aGRZjVQ> (2021, травень, 15).

${ }_{3}^{3}$ Українська правда (2021). Рейтинг довіри очолює Зеленський, Кличко - другий

<https://www.pravda.com.ua/news/2021/04/1/7288619/> (2021, травень, 15).

${ }^{4}$ Соціологічна група Рейтинг (2021). Оиінка медичної сфери в Украӥні (дані на 15.04.2021 p.)

<http://ratinggroup.ua/research/ukraine/ocenka_medicinskoy_sfery_v_ukraine_24-28_marta_2021.html?fbclid= IwAR1r5VhpvQgW9ERicJF5AVuT1EuHbrcgypZxWrZ9ZYRwBF7izYM0aGRZjVQ> (2021, травень, 15).

${ }^{5}$ Там само.

${ }^{6}$ Там само.
} 
Своєрідним тригером щодо реакції влади на настрої суспільства в рамках локдаунів та карантинів, став «сюжет про ресторан «Велюр», пов'язаний із народним депутатом, заступником голови депутатської фракції політичної партії «Слуга народу» Миколою Тищенком». У цьому сюжеті йшла мова про те, що в період локдауну саме цей заклад продовжив свою діяльність. В українському суспільстві така поведінка народного депутата стала тригером щодо подальшого зростання напруги та негативного ставлення до даної політичної партії, i, як слідство, подальшого зниження рівня довіри до діючого президента України. Цей заклад практично одразу набув статусу «загальнонаціонального мему», який почав асоціюватися з «Орвеллівським принципом «Усі тварини рівні, але деякі тварини рівніші за інших». Це створило мотивацію для протестів підприємців та дій мерів великих міст, які вимагали послаблення умов карантину саме через недотримання принципу справедливості при його реалізації». Таким чином, ми бачимо, що справедливість є тригером щодо поведінки та відношення громадян до політичної влади. «Порушення справедливості тут зіграло більшу роль, ніж невдоволення збитками, спричиненими карантином, чи нездатність далі терпіти незручності й обмеження. Загалом людина здатна терпіти практично безмежно, але лише в тому разі, якщо бачить у цьому сенс. Як тільки відчуття такого сенсу зникає, терпіння відразу закінчується». Влада зрозуміла, що потрібно реагувати негайно, тому, що протестний настрій суспільства піднімався ще вище, а довіра стрімко зменшувалася. Влада «відчула, що настрої у суспільстві змінюються і потрібно якось реагувати. Інша справа, наскільки в подальшому чутливою виявиться влада, особливо якщо йтиметься вже не про мінливі настрої, а про запити суспільства й суспільні потреби, які не можна ігнорувати тим, хто цю владу сподівається зберегти» ${ }^{1}$.

При цьому, з початку пандемії й до сьогодні Верховна Рада України та Кабінет Міністрів України прийняли разом більше 100 різних нормативно-правових актів. Це й закони, й постанови, які направлені на боротьбу з коронавірусом. I звичайно, «ще будуть інші пандемії та інші серйозні надзвичайні ситуації у сфері охорони здоров'я. Жоден уряд або багатостороння організація не може впоратися з цією загрозою поодинці. Не стоїть питання, чи це буде. Питання в тому, коли це станеться. Разом ми повинні бути більш підготовлені, щоб прогнозувати, запобігати, виявляти, оцінювати та ефективно реагувати на пандемії із забезпеченням високого рівня координації. Пандемія COVID-19 стала різким і болючим нагадуванням про те, що ніхто не $є$ у безпеці, поки всі не будуть у безпеці. Тому ми прагнемо забезпечити загальний та рівноправний доступ до безпечних, ефективних i недорогих вакцин, ліків і засобів діагностики для боротьби зцією та майбутніми пандеміями. Імунізація $\epsilon$ глобальним суспільним благом, і нам потрібно буде якомога швидше здійснювати розробку, виробництво та впровадження вакцин» ${ }^{2}$. Відповідно до цих дій керівники ВООЗ створили міжнародну програму "Access to COVID-19 Tools Accelerator" (ACT-A)», яка направлення на створення рівному доступу до медичних закладів, до вакцин, до лікування, до тестів тощо. Поки що мети не досягнуто, яле відповідні кроки робляться. I саме міжнародні договори та співробітництво мають можливість вплинути на цей процес.

Висновки. Пандемія стала тригером щодо змін на міжнародному рівні у відносинах між країнами. Зараз ми бачимо, як змінюються принципи міжнародної політики, формується новий світоустрій. Це потребує нових рішень в галузі безпекової політики на всіх рівнях. Україна потребує виваженого професійного осмислення сучасної ситуації (екстремальної ситуації) в різних галузях життєдіяльності суспільства та держави. Пандемія стала тригером соціально-політичних змін не тільки в Україні, а й всьому світі, а це вимагає діалогу між країнами за для подолання пандемії. Необхідним $є$ вироблення відповідних політичних та управлінських рішень, що стане запорукою для проведення зрозумілої та ефективної політики задля покращення ситуації в усьому світі.

\section{References:}

1. Bilodid, I. K. (ed.) (1975). Slovnyk ukrayinskoyi movy: v 11 tomakh [Dictionary of the Ukrainian language: in 11 volumes]. Kyiv: Naukova Dumka, 6, 43. [in Ukrainian].

2. Herasymchuk, S., Shelest, H. (2020). Stsenariyi i trendy 2021: Mizhnarodna polityka [Scenarios and trends 2021: International politics]. Kyiv: Friedrich Ebert Foundation. [in Ukrainian].

\footnotetext{
${ }^{1}$ Міщенко, М. (2020). Пандемія і політики. Украӥнський інтерес <https://uain.press/articles/pandemiya-i-polityky-1234974> (2021, травень, 15).

2 Свропейська правда. Міжнародна безпека та євроінтеграція України (2021). Колективне комюніке керівників вооз, європейської ради, а також лідерів украӥни та 22 краӥн світу. як здолати пандемію: спільна стаття 24 глав держав та урядів <https://www.eurointegration.com.ua/articles/2021/03/30/7121495/> (2021, травень, 15).
} 
3. Yevropeyska pravda. Mizhnarodna bezpeka ta yevrointehratsiya Ukrayiny [European truth. International Security and European Integration of Ukraine] (2021). Kolektyvne komyunike kerivnykiv VOOZ, Yevropeyskoyi Rady, a takozh lideriv Ukrayiny ta 22 krayin svitu. Yak zdolaty pandemiyu: spilna stattya 24 hlav derzhav ta uryadiv [Collective communiqué of WHO leaders, the European Council, as well as leaders of Ukraine and 22 countries. How to overcome a pandemic: a joint article by 24 heads of state and government] <https://www.eurointegration.com.ua/articles/2021/03/30/7121495> (2021, May, 15). [in Ukrainian].

4. Laboratoriya zakonodavchykh initsiatyv [Laboratory of Legislative Initiatives] (2020). Virus i polityka: Yak pandemiya koronavirusu vplyvaye na politychni protsesy? [Virus and politics: How does the coronavirus pandemic affect political processes?] <https://parlament.org.ua/2020/03/30/virus-i-politika-yak-pandemiyakoronavirusu-vplivaye-na-politichni-protsesi/> (2021, May, 15). [in Ukrainian].

5. Lukanova, V. (2018) Pandemiya yak antysystema: analiz konstytutyvnykh aspektiv [Pandemic as an antisystem: analysis of constitutive aspects]. Naukovo-teoretychnyy almanakh Hrani [Scientific and theoretical almanac Grani], 21, 11, 87-89. [in Ukrainian].

6. Lukashevskaya, A.(2020). Chto takoye pandemiya i epidemiya: obyasnyayem raznitsu na primere koronavirusa. Zdorovye.24. [What is a pandemic and an epidemic: explaining the difference using the example ofthe coronavirus]. <https://health.24tv.ua/ru/chto_takoe_pandemija_chto_takoe_jepidemija_raznica_jetih_ponjatij_n1287883> (2021, May, 15). [in Ukrainian].

7. Mishchenko, M. (2020). Pandemiya i polityky [Pandemic and politics]. Ukrayinskyy interes [Ukrainian interest] <https://uain.press/articles/pandemiya-i-polityky-1234974> (2021, May, 15). [in Ukrainian].

8. Pekhnyk, A. (2017). Rozpodil vlady: suchasnyy pohlyad [Distribution of power: a modern view]. Aktualni problemy polityky [Current policy issues], 60, 48.

9. Sotsiolohichna hrupa Reytynh [Sociological group Rating] (2021). Otsinka medychnoyi sfery v Ukrayini (dani na 15.04.2021 r.) [Assessment of the medical sphere in Ukraine (data as of April 15, 2021)] <http://ratinggroup.ua/research/ukraine/ocenka_medicinskoy_sfery_v_ukraine_24-28_marta_2021.html?fbclid= IwAR1r5VhpvQgW9ERicJF5AVuT1EuHbrcgypZxWrZ9ZYRwBF7izYM0aGRZjVQ> (2021, May, 15). [in Ukrainian].

10. Tkachenko, T. (2020). Pandemiya Covid-19 - hlobalno-emotsiynyy tryher sfery hostynnosti: osoblyvosti i vyznannya [The Covid-19 pandemic is a global emotional trigger for hospitality: features and recognition]. Aktualnye nauchnye yssledovanyya v sovremennom myre [Current scientific research in the modern world], 6-4 (62), 56-61. [in Ukrainian].

11. Ukrayinska pravda [Ukrainian Truth] (2021). Reytynh doviry ocholyuye Zelenskyy, Klychko - druhyy [The trust rating is headed by Zelensky, Klitschko is second] <https://www.pravda.com.ua/news/2021/04/1/7288619/> (2021, May, 15). [in Ukrainian].

12. Yatsyk, I. S. (2009). Hranychna sytuatsiya ekzystentsiyi vchynku: povnota ekzystentsiyi u filosofiyi Nikolo Abbanyano ta «lyudyna na mezhi» Karla Yaspersa [The extreme situation of the existence of the act: the completeness of existence in the philosophy of Niccolo Abbaniano and "man on the edge" by Karl Jaspers]: dysertatsiya na zdobuttya naukovoho stupenya kandydata filosofskykh nauk [the dissertation for the degree of candidate of philosophical sciences]. Zhytomyr: Ivan Franko Zhytomyr State University. [in Ukrainian]. 